\title{
Permeability Measuremens of Brazilian Eucalyptus
}

\author{
Marcio Rogério da Silva, , Gilmara de Oliveira Machado ${ }^{\mathrm{a}}$,Jay Deiner ${ }^{\mathrm{b}}$, Carlito Calil Junior ${ }^{\mathrm{a}}$ \\ ${ }^{a}$ Laboratório de Madeiras e Estrutura de Madeiras, Escola de Engenharia de São Carlos, \\ Universidade de São Paulo - USP, \\ Av. Trabalhador São-carlense, 400, CP 780, CEP 13566-590, São Carlos, SP, Brazil \\ ${ }^{\mathrm{b}}$ Instituto de Química de São Carlos, Universidade de São Paulo - USP, \\ Av. Trabalhador São-carlense, 400, CP 780, CEP 13566-590, São Carlos, SP, Brazil
}

Received: April 30, 2009; Revised: April 30, 2010

\begin{abstract}
The permeability of Brazilian Eucalyptus grandis and Eucalyptus citriodora wood was measured in a custom build gas analysis chamber in order to determine which species could be successfully treated with preservatives. Liquid permeability was tested using an emulsion of Neen oil and a control of distillated water. Air was used to test the gas phase permeability. For both Eucalyptus grandis and Eucalyptus citriodora, the longitudinal permeability of gas was shown to be about twice as great as the liquid phase permeability. No radial permeability was observed for either wood. The permeability of air and water through the sapwood of Eucalyptus grandis was greater than that through the sapwood of Eucalyptus citriodora. The permeability of neen oil preservative through the sapwood of Eucalyptus grandis was also greater than through the sapwood of E. Citradora, but the difference was not statistically significant. Scanning Electron Microscopy images showed that the distribution and obstruction in the vessels could be correlated with observed permeability properties. Irrespective of the causes of differences in permeability between the species, the fluid phase flux through the sapwood of both species was significant, indicating that both Eucalyptus grandis and Eucalyptus citriodora could be successfully treated with wood preservative.
\end{abstract}

Keywords: wood permeability, Eucalyptus grandis, Eucalyptus citriodora, Scanning Electron Microscopy (SEM), chemical composition

\section{Introduction}

Eucalyptus is a diverse genus of trees, comprising over 800 species adapted to nearly every environment ${ }^{1}$. Initially from Australia, Eucalyptus plantations can now be found in more than 90 countries with the largest overseas plantations being in Brazil. Eucalyptus was introduced to Brazil in 1910 for timber substitution and charcoal production. Nowadays, almost 4,000,000 ha of Eucalyptus are planted in Brazil (primarily in the southwest and northwest), and the genus is responsible for about $70 \%$ of the country's sustainable forest production. The primarily users of Eucalyptus are the cellulose and paper industries, the steel industry and the particle board industry ${ }^{2}$.

In response to the urgent need to preserve the slow growth tropical rain forests of Brazil, it has recently been proposed that the uses of Eucalyptus grandis (E.grandis) and Eucalyptus citriodora (E. citriodora) be expanded to include use as structural timber. Eucalyptus in general, and these species in specific, show great potential as structural timber, due to their favorable physical and mechanical properties ${ }^{3}$, rapid growth rates, and adaptability to conditions in Brazil. However, to use this resource wisely, and to select the best possible Eucalyptus species for construction purposes, it is necessary to further explore the physical and chemical properties of the wood. Permeability is one key physical property that must be assessed in order to select a wood that readily accepts preservative and hence can be easily preserved ${ }^{4-8}$. Permeability of wood also affects processing time and product quality, both of which affect price pre-12 $^{7,}$

Permeability is defined as the ease with which a fluid flows through a porous material under the influence of a pressure gradient ${ }^{13}$. Permeability is influenced by the porosity of the substance (the fractional void volume), the degree of occlusion of the space through which the fluid flows, the diameter of the space through which the fluid flows, the viscosity of the fluid, and the surface interactions between the fluid and the walls of the vessel. All of these factors come into play when assessing the permeability (and hence preservability of a wood). For example, the youngest part of the tree, the sapwood, has relatively open vessels for water and mineral conduction and hence a high permeability. In contrast, the heartwood has a higher proportion of low molecular weight organics (known as extractives) that can cause total or partial occlusion of fluid conduction vessels. Hence, the heartwood generally has a much lower conduction than the sapwood. However, the same blockages that prevent preservative penetration in heartwood also prevent penetration by insects and xylophages. In the sapwood, the same permeability that creates vulnerability to insect and xylophagic attack also creates an opportunity for preservative impregnation ${ }^{8}$. Similarly, fast growing woods generally have a high permeability which drives both the low natural resistance as well as the preservability ${ }^{14}$.

In addition to its relevance to impregnation, permeability is also a property that affects the how easily a wood sample can be glued, painted or varnished. In particular, the ability to accept adhesive has been tied to the permeability, density, and porosity of a species. These factors have, in turn, been tied to the underlying anatomical structure of the wood. Thus, dicots usually have greater difficulties accepting adhesive as compared to conifers ${ }^{15}$.

In studying permeability, it is necessary to acknowledge that permeability value depends strongly on the viscosity of the probe fluid 
used in the measurement. Viscosity can be thought of as a resistance to flow or, more precisely, as the proportionality constant that relates the shear stress on a fluid to the rate of strain. Thus, the greater the viscosity, the lower the rate of fluid flow and hence the lower the measured permeability. Viscosities of probe fluids can vary widely. For example, the low temperature viscosity of water (measured in Pa.s) is two orders of magnitude higher than the viscosity of air ${ }^{7,9,10}$.

The objectives of this study is to compare the permeability of E. grandis and E. citriodora, to compare the permeability of different fluids, and to correlate the permeability of wood with its chemical composition and with its anatomical structure (specifically the presence or absence of blockages in the pores). This information will be used to determine which species (E. grandis, E. citriodora) and which part of the wood (heartwood or sapwood) will have the highest flux, and hence which are most labile to preservative impregnation. This insight will help predict which species may be the best source of fast growing structural timber and how it may be most effectively treated.

\section{Experimental}

During the assays, the E. grandis and E. citriodora samples were kept in an acclimatized room where the moisture content of the samples was maintained at $12 \%{ }^{[16]}$.Under these conditions, the density of $E$. grandis was $723 \mathrm{~kg} \cdot \mathrm{m}^{-3}$ (sapwood) and $720 \mathrm{~kg} \cdot \mathrm{m}^{-3}$ (heartwood) and the density of E. citriodora was $950 \mathrm{~kg} \cdot \mathrm{m}^{-3}$ (sapwood) and $1,076 \mathrm{~kg} \cdot \mathrm{m}^{-3}$ (heartwood). In order to ensure that the tested samples were representative, the wood samples were obtained by cutting disks from a long trunk. These disks were then cut into pieces, which were sized appropriately for each of the different measurements.

For the chemical characterization, the samples of wood were cut into pieces capable of passing through a 42 mesh screen $(0.355 \mathrm{~mm}$ pore size). Before each chemical assay, the moisture content of all samples was determined in triplicate ${ }^{17}$. Subsequent to moisture content determination, the samples were treated in a soxhlet extractor using water and organic solvents (cyclohexane and ethanol, P.A. grade). The extraction was begun by soaking the samples in ethanol for 4 hours at room temperature $\left(25^{\circ} \mathrm{C}\right)$. Next, the samples were placed in a 1:1 cyclo-hexane/ethanol solution for 8 hours in order to remove the hydrophobic substances. Next, the same samples were subjected to a 3 hour extraction in distilled water. Finally, the samples were dried in an oven at $60{ }^{\circ} \mathrm{C}$. During the drying process, fresh air was continuously circulated through the oven. The extractive content was determined by the mass difference of the dry samples, before and after the treatment procedures.

Once the extractive-free samples were obtained, the ash content was established according to norm TAPPI T211 om-93 $1985^{[18]}$. The lignin content was determined by the sum of the soluble and insoluble lignin fractions according to norm TAPPI T222 om- $98^{[19]}$ and TAPPI T250 1985 ${ }^{[20]}$,respectively. High performance liquid chromatography (HPLC) was used to analyze the cellulose and hemicellulose content, as specified in TAPPI T $249 \mathrm{~cm}-851985^{[21]}$. A minimum of three samples were tested in order to establish a standard deviation in the method.

Measurements of permeability to gases and to liquid in the longitudinal and radial directions of E. grandis and E. citriodora were carried out in an in-house built apparatus (Figure 1). Gas permeability was measured with atmospheric air. Liquid permeability was measured with distilled water and with a Neen oil based preservative. The preservative used in the permeability measurements was a diluted aqueous emulsion (in distilled water) containing $0.1 \%$ Neem oil and $0.1 \%$ surfactant. The latter was synthesized in house from the reaction between castor oil and dimethylamine. In addition, $2 \%$ hexametaphosphate was added to the surfactant mixture to decrease the viscosity ${ }^{22}$.
The cylindrical wood samples used in the permeability measurements were $20 \mathrm{~mm}$ in diameter and $50 \mathrm{~mm}$ in length. Care was taken to ensure that all samples for a given permeability measurement had come from the same tree. For the gas and liquid phase permeability measurements of E. citriodora, 20 cylindrical samples were taken in the longitudinal and radial directions for both the sapwood and the heartwood. For the gas phase permeability of E. grandis, 20 cylindrical samples were taken in the longitudinal and radial directions of both the sapwood and the heartwood. For liquid phase permeability measurements of E. grandis, 11 samples were taken in the longitudinal and radial directions of the sapwood and 15 samples were taken in the longitudinal and radial directions of the heartwood. All the measurements were performed at room temperature and a manometer coupled to a vacuum pump was used to measure the initial and final pressure during the assay. During radial (or longitudinal) permeability measurements, the side of the samples was coated with epoxy resin to restrict flow in the longitudinal (or radial) direction. During the permeability the samples were placed in the apparatus individually, applying a vacuum, and then measuring the flow rate, as shown in Figure 1.

For permeability to gases, Figure 1a, the apparatus consisted of three rotameters (flow meter) to measure the airflow rate in the ranges of 20 to $180 \mathrm{~mL} / \mathrm{min}, 10$ to $100 \mathrm{~L} / \mathrm{h}$ and 100 to $1100 \mathrm{~L} / \mathrm{h}$. A baseline for the atmospheric gas flow rate was achieved by applying an initial vacuum of $91 \mathrm{kPa}$ for 2 minutes (to stabilize the system) and then measuring the airflow rate on the rotameter. Liquid permeability was measured using the apparatus described in Figure $1 \mathrm{~b}$ and a procedure similar to that described for the gas permeability measurements. Samples were tested with two different liquids (water alone and the Neem oil preservative).

To measure the permeability to liquid, the test liquid was placed in a $50 \mathrm{~mL}$ burette and a vacuum was applied. The liquid was then allowed to pass through the sample until a constant flow was obtained. Once constant flow was obtained, a flow rate was established by measuring the time necessary for $30 \mathrm{~mL}$ of the liquid to pass through the samples.

The permeability to gases and to liquid was calculated by applying Darcy's law ${ }^{13}$ to the flow rates obtained as described above.

Samples of E. grandis and E. citriodora were examined by scanning electron microscopy (SEM) using a Zeiss-Leica instrument model 440. An electron beam acceleration of $20 \mathrm{kV}$ was applied. All samples analyzed were gold coated in a BAL-TEC (MED 020) coating system.

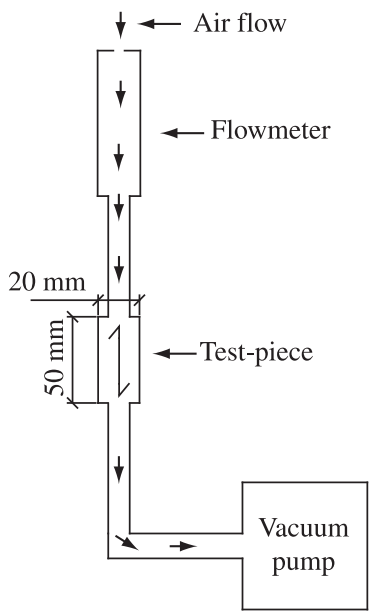

(a)

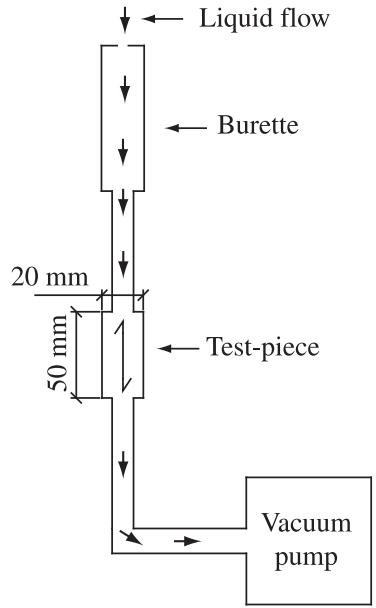

(b)
Figure 1. Apparatus for a) gas and b) liquid permeability measurement. 
Statistical analyses were conducted using Statistical Analysis System (SAS) software. Permeability results for species in the sapwood and heartwood in each type of fluid were compared using variance analysis (ANOVA) and the Tukey test at $95 \%$ confidence interval.

\section{Results and Discussion}

Table 1 show the permeability to gas and to liquid of the sapwood of $E$. citriodora and the heartwood and sapwood of $E$. grandis. Neither liquid nor air flow was detected in the radial direction for either species of Eucalyptus in the study. Also, the heartwood of E. citriodora does not present permeability to gas or liquid. All of these results are in accordance with the literature ${ }^{7,23}$.

Figure 2 shows a better visualization of permeability behavior than Table 1 for different fluid types.

Sapwood to heartwood transformation reduces intercellular flow. The main reason for this decrease is the closure of the vessels by tyloses or occlusion by organic deposits such as extractives and

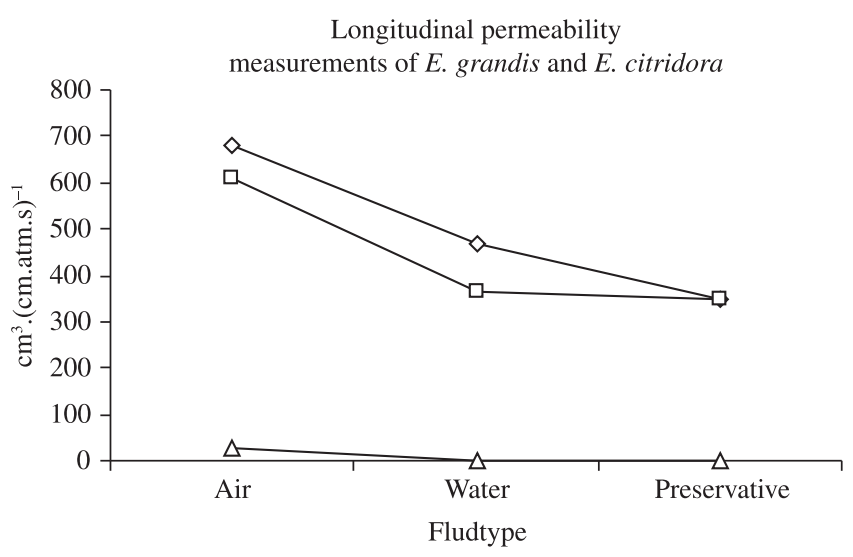

$\checkmark-$ E. grandis - Sapwood $\neg-$ E. citriodora - Sapwood $\triangle$ E. grandis - Heartwood

Figure 2. The longitudinal permeability of E. grandis and E. citriodora. encrustation with ligno-complex components ${ }^{6}$, Figures $3 \mathrm{a}$ and $4 \mathrm{a}$. The results of the permeability measurements of E. grandis confirm this information. Specifically, the permeability in heartwood is about 28 times less than in sapwood. Similarly, there is no measurable permeability for the heartwood of E. citriodora.

Given that the measured permeability depends inversely on the viscosity of the fluid used to perform the measurement ${ }^{14}$, it is expected that the permeability to air (viscosity of $0.0182 \mathrm{mPa}$.s at $298 \mathrm{~K}$ ) would be far greater than the permeaibility to distilled water (viscosity of $1 \mathrm{mPa} . \mathrm{s}$ at $298 \mathrm{~K}$ ) or Neen oil preservative (viscosity of $4 \mathrm{mPa} . \mathrm{s}$ at $298 \mathrm{~K}$ ). Indeed, as seen in Table 1, it is clear that the permeability to air is vastly greater in the sapwood of E. grandis and E. citriodora. The statisticaly analysis shoes that the permeability to air and distilled water are different between the two species with the sapwood of $E$. grandis displaying a greater flux as compared to that of E. citriodora. Strangely, while the permeability of the $E$. grandis sapwood to neen oil preservative is greater than the corresponding permeability in E. citriodora, the difference is not statisitcally significant. However, the lack of statistical significance must be viewed with suspicion as the test samples of E. citriodora sapwood used for the permeability tests in water were taken a year before those used to test the permeability of Neen oil preservative. Further, despite the $3 \mathrm{mPa}$.s difference in viscosity between the water and neen oil, the measured permeabilities were quite similar.

The results of the wood composition analysis are shown in Table 2. The extractives are defined as the sum of all compounds soluble in organic solvent plus those soluble in water. The inorganic salt content is termed "ashes". As is evident from Table 2, the majority of the wood samples' masses are derived from extractives, hemicellulose, cellulose and lignin. Ash contributes only a few percent to the wood mass.

The composition data shown in Table 2 are in agreement with other data for Eucalyptus grown in Brazil ${ }^{24,25}$. In general, Eucalyptus possesses relatively low ash content. This is especially true in tropical countries where the ash content of this genus generally varies between $0.2 \%$ and $1 \%$. The extractives can constitute up to $8 \%$ of the mass of dry wood in temperate climate species, and up to $20 \%$ in tropical species ${ }^{4,26,27}$. Generally the heartwood contains phenolic compounds, gums, resins, and other materials that make the extractive content higher for heartwood.

Table 1. Longitudinal permeability measurement of E. grandis and E. citriodora.

\begin{tabular}{llccc}
\hline \multicolumn{2}{c}{ Units $-\mathrm{cm}^{3} \cdot(\mathrm{cm} . \text { atm.s })^{-1}$} & Air & Water & Preservative \\
\hline \multirow{2}{*}{ Sapwood } & E. grandis & $681 \pm 74.43 \mathrm{a}$ & $470 \pm 121 \mathrm{a}$ & $349 \pm 99.54 \mathrm{a}$ \\
\multirow{2}{*}{ Heartwood } & E. citriodora & $612 \pm 26.74 \mathrm{~b}$ & $365 \pm 75.27 \mathrm{~b}$ & $347 \pm 66.86 \mathrm{a}$ \\
& E. grandis & $25 \pm 4.04 \mathrm{c}$ & $0.42 \pm 0.25 \mathrm{c}$ & $0.12 \pm 0.04 \mathrm{~b}$ \\
& E. citriodora & 0.0 & 0.0 & 0.0 \\
\hline
\end{tabular}

Values are mean \pm standard deviation (SD). Means followed by the same letter are not significant (Tukey $\alpha=5 \%$ ).

Table 2. E. grandis and E. citriodora chemical characterization.

\begin{tabular}{lrrrrr}
\hline \multirow{2}{*}{ Compound (\%) } & \multicolumn{2}{c}{ E.grandis } & & \multicolumn{2}{c}{ E. citriodora } \\
\cline { 2 - 6 } \cline { 3 - 6 } & \multicolumn{1}{c}{ Sapwood } & Heartwood & & Sapwood & Heartwood \\
\hline Extractives & $7.97 \pm 0.21$ & $6.58 \pm 1.20$ & & $3.29 \pm 0.06$ & $14.47 \pm 0.21$ \\
Ashes & $0.35 \pm 0.01$ & $0.06 \pm 0.01$ & & $0.32 \pm 0.01$ & $0.19 \pm 0.01$ \\
Hemicellulose & $15.65 \pm 0.45$ & $16.05 \pm 0.91$ & & $19.40 \pm 0.21$ & $18.44 \pm 0.04$ \\
Cellulose & $48.73 \pm 2.50$ & $46.01 \pm 0.58$ & & $46.05 \pm 1.00$ & $44.51 \pm 1.08$ \\
Lignin & $33.90 \pm 0.23$ & $33.08 \pm 0.04$ & & $31.14 \pm 0.38$ & $31.80 \pm 0.03$ \\
\hline
\end{tabular}

Data are mean \pm standard deviation (SD) for 3 samples. 


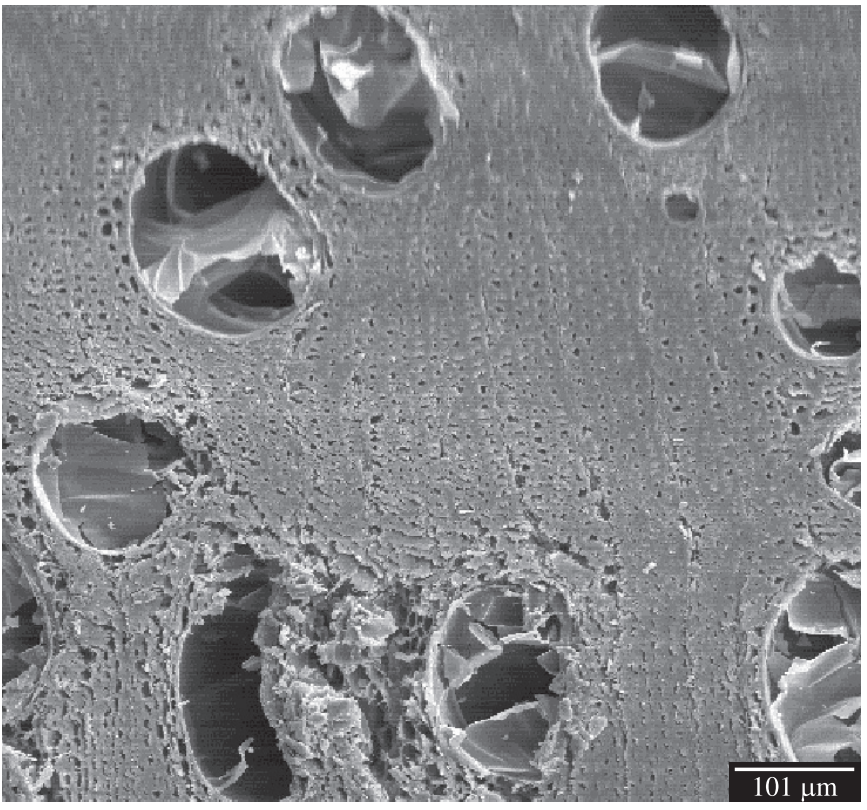

(a) Heartwood - transverse direction

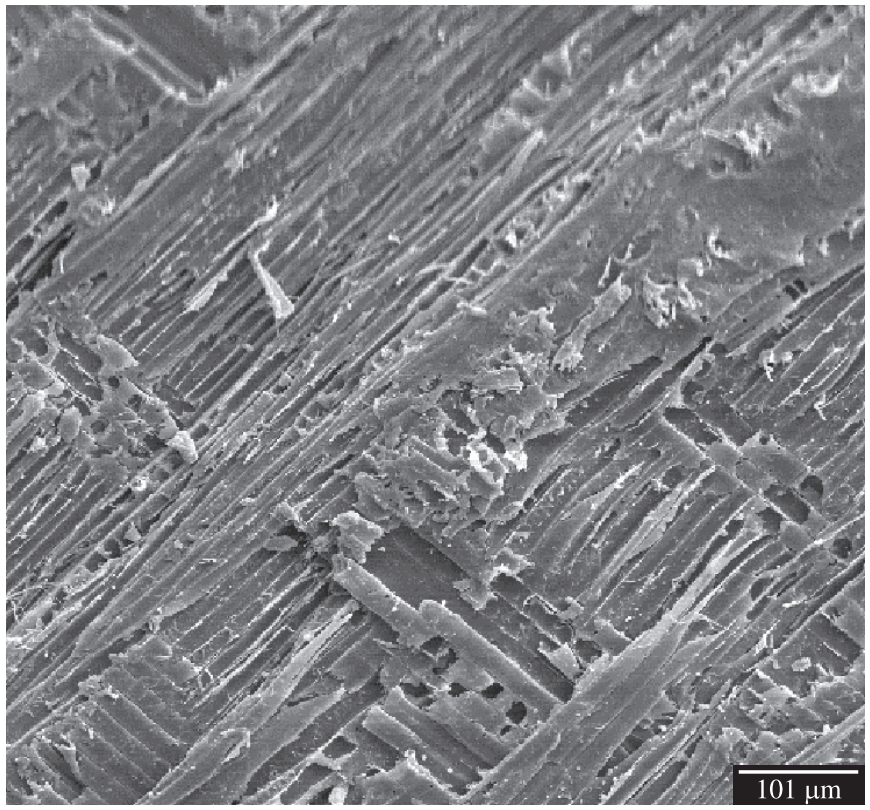

(c) Heartwood - radial direction

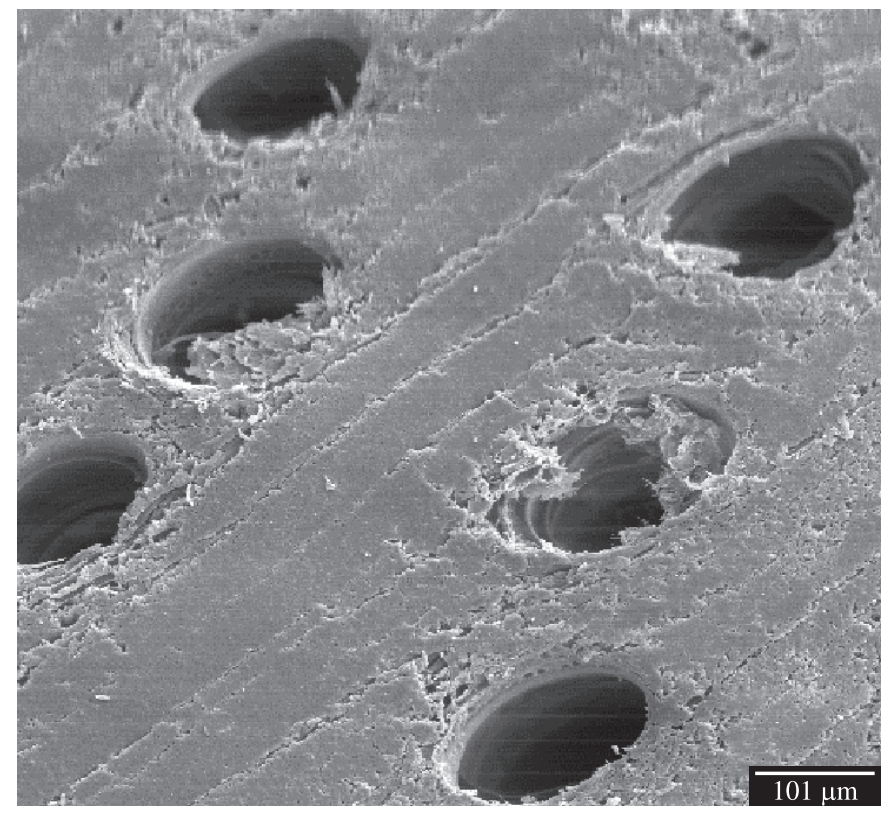

(b) Sapwood - transverse direction

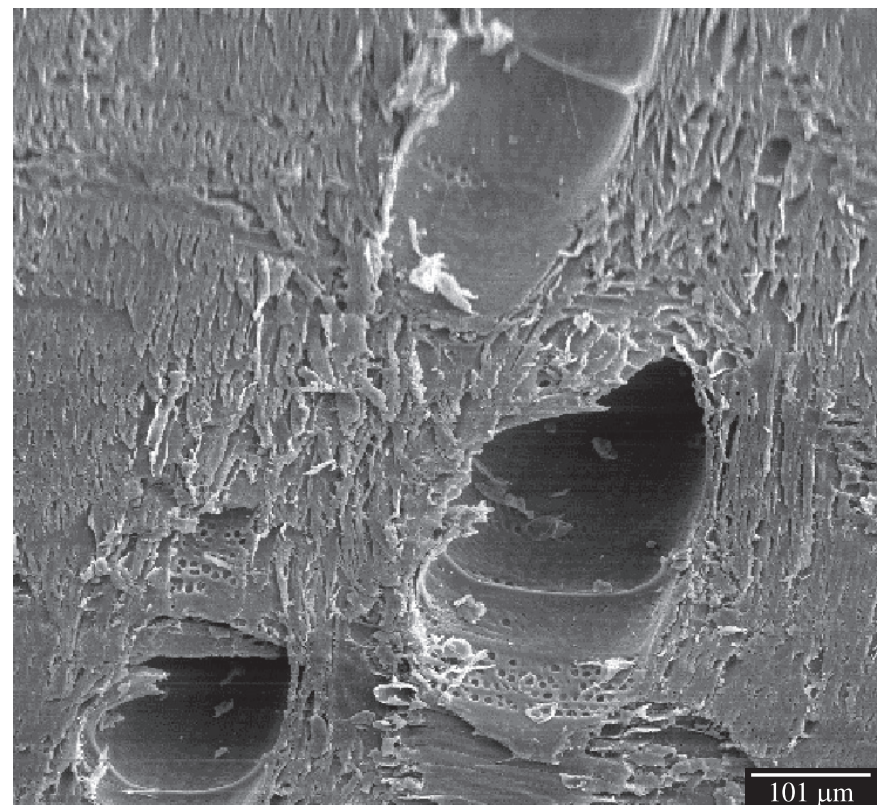

(d) Sapwood - radial direction

Figure 3. Test-pieces surface of E. grandis, 100× magnification was used.

Table 2 shows that the extractive content of heartwood is similar to sapwood for E. grandis, which may explain why the heartwood of $E$. grandis does display some permeability (Table 1). In contrast, the high content of extractives in the E. citriodora heartwood may explain the lack of permeability to both liquids and gases.

Regarding lignin and polysaccharide content, the results are also in accord with data already in the literature ${ }^{25,28}$. Lignin and polysaccharides represent the bulk of the E. grandis and E citriodora composition. The cellulose content is about $45 \%$, the lignin $30 \%$, and the hemicelulose $16 \%$.

Figure 3 and 4 show the SEM images of E. grandis and E. citriodora. Numerous studies have been reported in the literature concerning observation of penetration in wood using optical microscopy techniques because permeability is highly dependent on the anatomical structure of wood and the free space present in the pores ${ }^{23}$

Both species of eucalyptus are relatively heterogeneous in their structure, having a great complexity of cell forms. In addition to fibers and rays, eucalyptus has cells of relatively large diameter known as vessels or pores. The flow of fluids in the longitudinal direction is largely controlled by the size and number of vessels. Because of their tube-like structure, vessels serve as the main natural passages for conduction of preservatives in the direction of the grain of the wood.

Table 1 shows that the heartwood of E. grandis has a small, but measurable, permeability to air and liquid. The SEM images (Figure 3a) show that the low permeability in the heartwood of E. grandis is likely due to the partial blocking of vessels by tyloses. In contrast, no heartwood permeability is observed for E. citriodora 


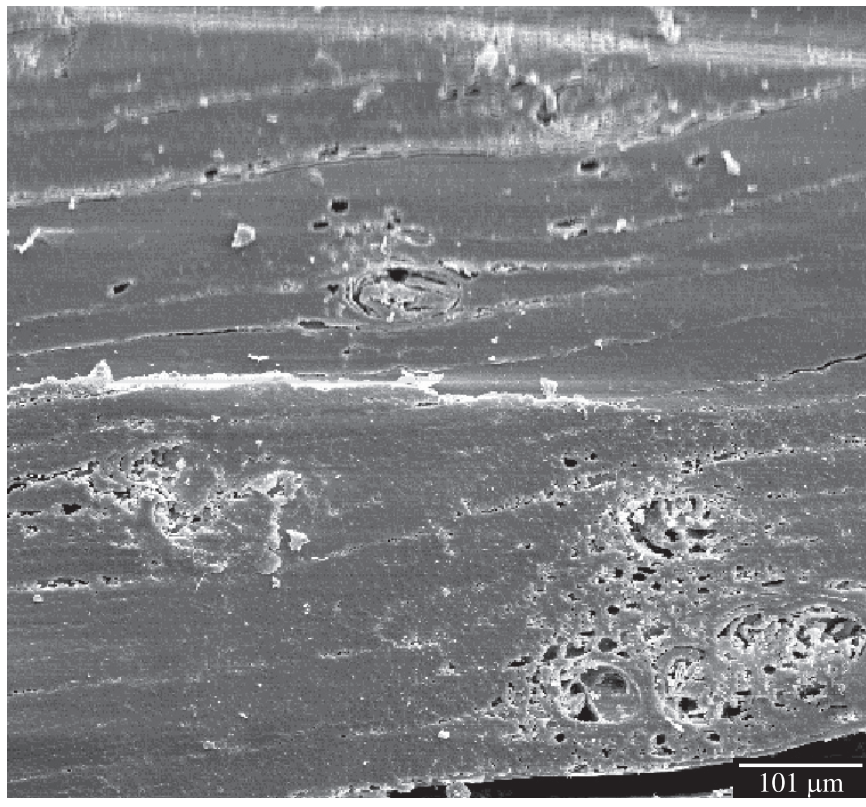

(a) Heartwood - transverse direction

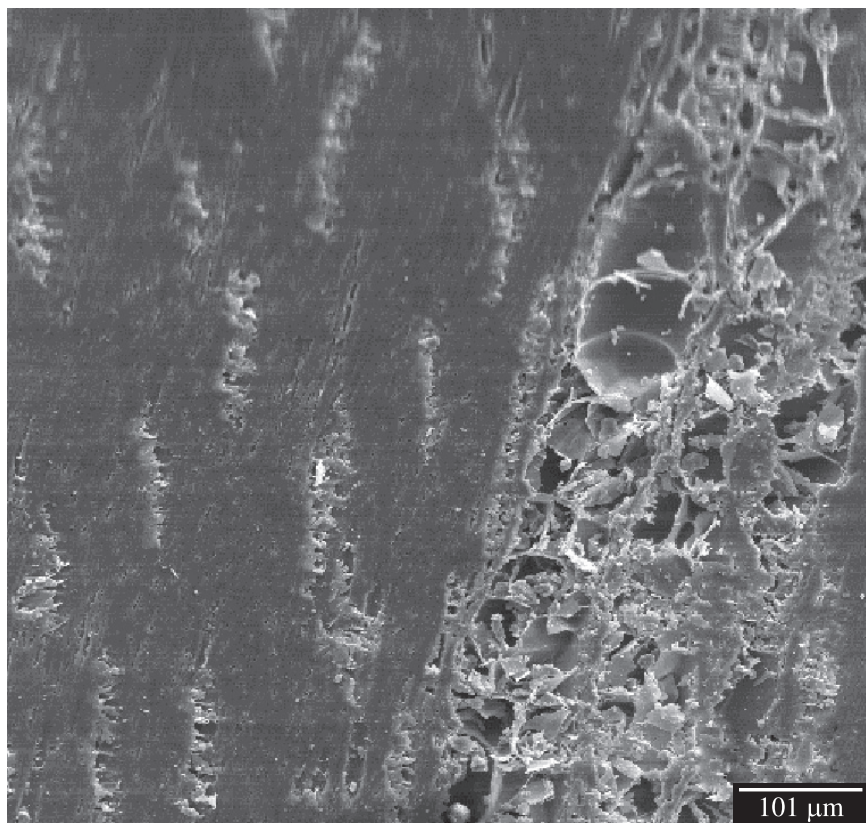

(c) Heartwood - radial direction

Figure 4. Test-pieces surface of $E$. citriodora, 100× magnification was used.

because the vessels are completely obstructed by tyloses, as seen in Figure 4a. For both E. grandis and E. citriodora, the SEM images of the heartwood and sapwood (Figures $3 \mathrm{c}$ and $\mathrm{d}$ and Figures $4 \mathrm{c}$ and $\mathrm{d}$ ) show almost full occlusion of pores in the radial direction. These blockages likely account for the fact that no permeability is observed in the radial direction of either sample.

An attempt was made to correlate the observed pore size and density of the sapwood of $E$. grandis and E. citriodora with the values obtained in the longitudinal permeability study (Table 1). First, the quantity of vessels from sapwood for both species of eucalyptus was calculated from the SEM images. $E$ grandis has 160 vessels per $\mathrm{cm}^{2}$ with an average vessel diameter of $0.18 \mathrm{~mm}$. E. citriodora has 295 vessels per $\mathrm{cm}^{2}$ with an average vessel diameter of $0.093 \mathrm{~mm}$. Based on this simple geometrical analysis the sapwood of $E$. grandis

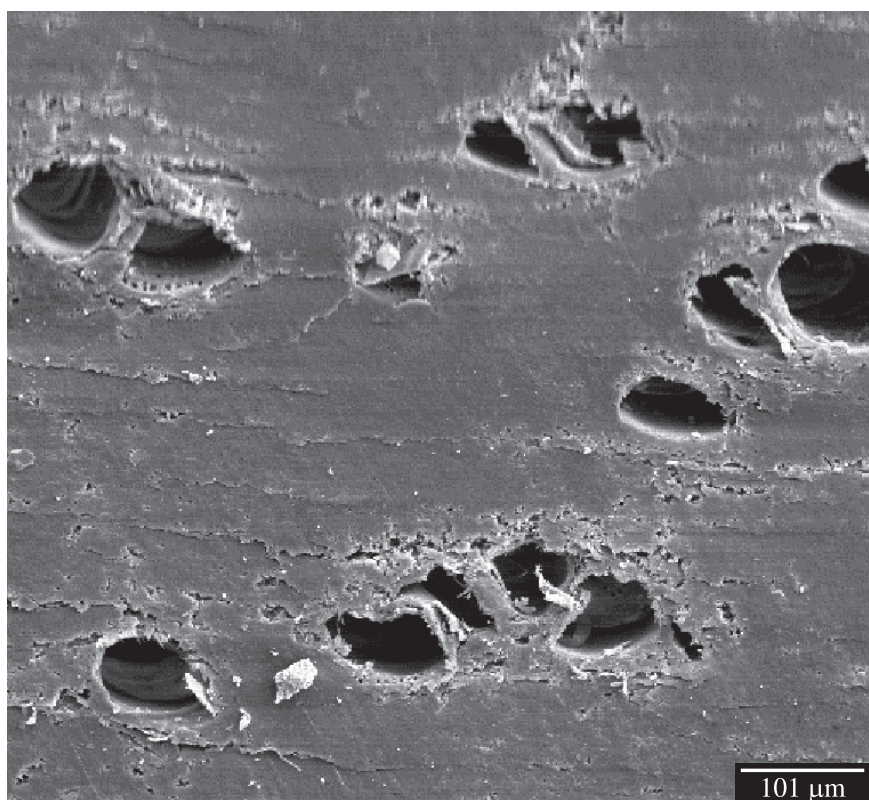

(b) Sapwood - transverse direction

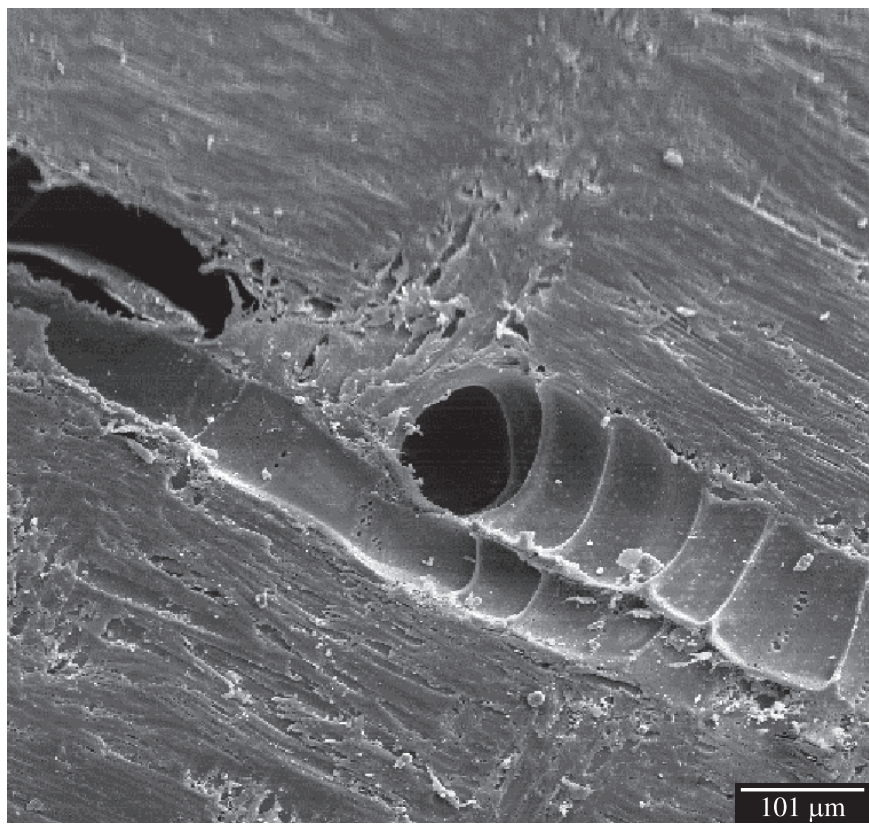

(d) Sapwood - radial direction

would be expected to have a measurably higher permeability as compared to E. citriodora. In general, this prediction is in accord with the experimental measurements of permeability described above. However, the extent of the difference is not as great as would be predicted by the simple geometrical analysis. There are a few reasons why the geometrical analysis may not quantitatively correlate with the observed permeabilities. First, wood is highly anisotropic so a calculation based on a microscopic measurement may not be truly reflective of the overall sample composition. Second, the pore to pore connections in the two samples may be different which may also affect the observed permeability.

Table 3 shows the porosity of the species in this study ${ }^{13}$. As noted previously, the porosity and the permeaibility can be expected to correlate well with the facility for wood preservation. 
Table 3. Porosidade do E. grandis e E. citriodora.

\begin{tabular}{cccccc}
\hline Espécie & \multicolumn{2}{c}{ E. grandis } & & \multicolumn{2}{c}{ E. citriodora } \\
\cline { 1 - 3 } \cline { 5 - 6 } Parte do lenho & Alburno & Cerne & & Alburno & Cerne \\
Porosidade (Va) $\%$ & 41,35 & 39,6 & & 29,25 & 20,56 \\
\hline
\end{tabular}

The sapwood of E. grandis has the greatest permeability followed by the sapwood of E. citriodora. These observations correlated with the porosoties presented in Table 3. One notable exception to the correlation between porosity and permeability is the heartwood of E. grandis. While the heartwood of E. grandis has a low permeability, it has a high porosity. However, it must be noted that the heartwood of $E$. grandis has a relatively high quantity of extractives that partially block the pores.. Notably, the heartwood of E. citriodora has an null permeability due to the very high quantity of extractives (Table 3).

\section{Conclusion}

The sapwood of E. grandis and E. citriodora are highly permeable. As such, the sapwood of E. grandis and E. citriodora are likely to be good candidates for impregnation with fluid preservative. In general the permeability of the sapwood of $E$. grandis was higher than that of E. citriodora. In the case of air and water, the difference was statistically significant. In the case of neen oil preservative, the difference was ambiguous due to differences in sample handling. However, the statistically significant difference to the permeability of two fluids is strong enough to indicate that $E$. grandis may be a slightly better candidate for preservative impregnation. Due to the zero or near zero permeability of heartwood from both Eucalyptus species, this part of the tree is not recommended for fluid impregnation.

Irrespective of the species of Eucalyptus and whether in heartwood or sapwood, the factor that was most predictive of permeability was how open or blocked the pores were. No liquid or air flux was detected in the radial direction for sapwood and heartwood of both species of Eucalyptus. This lack of transport was attributed to a near full occlusion of radial pores as observed in SEM. The heartwood of E. citriodora presents neither permeability to air nor to liquid in the longitudinal direction. This is attributed to the high quantity of extractives present in E citriodora and the resultant complete blockage of heartwood pores by tyloses in E. citriodora. Heartwood of $E$ grandis has a small, but measurable permeability to air and liquid. The SEM images show that the low permeability in the heartwood of E. grandis is due to the partial blocking of vessels by tyloses and the relatively high quantity of extractives present in the heartwood as compared to the sapwood. The high permeability of the sapwood of both species is due to the large number of unblocked pores.

\section{Acknowledgements}

The authors would like to acknowledge FAPESP (Fundação de Amparo à Pesquisa do Estado de São Paulo) for the financial support given to this research. Also Lamem (Laboratório de Madeiras e Estrutura de Madeiras) and IQSC (Instituto de Química de São Carlos) are thanked for providing laboratory support.

\section{References}

1. Eucalyptus Online Book. [2008 Aug. 10]. Available from: http://www. eucalyptus.com.br/disponiveis.html.

2. Sociedade Brasileira de Silvicultura. Fatos e Números do Brasil Floresta. 2007. $110 \mathrm{p}$.

3. Pereira JCD, Sturion JÁ, Higa AR, Higa RCV and Shimizu JY. Características da madeira de algumas espécies de eucalipto plantadas no Brasil. Colombo, PR: Embrapa Florestas; 2000. (Documentos, 38).

4. Fengel D and Wegener G. Wood: chemistry, ultrastructure reactions. New York: Walter de Gruyter; 1984.

5. Sjöström E. Wood chemistry: fundamentals and applications. London: Academic Press; 1981.

6. Calil Jr C, Rocco Lahr FA and Dias AA. Dimensionamento de elementos estruturais de madeira. Rio de Janeiro: Manole Ltda; 2003.

7. Hansmann C, Wimmer WGR and Teischinger A. Permeability of wood - A review. Drevarsky Vyskum. 2002; 47(4):1-16.

8. Déon G. Manual de preservação das madeiras em clima tropical. Salvador: ITTO; 1989. 116 p. (Série Técnica, 3).

9. Hunt MG and Garrat GA. Wood Preservation. New York: Mc Grawhill; 1963.

10. Cassens DL. Selection and use of preservative: treated wood. Madison, US: Forest Products Society; 1995.

11. Fenton CC and Degroot RC. The recycling potenticial of preservative treated wood. Forest Products Journal. 1996; 46(7-8):37-46.

12. Eaton RA and Hale MDC. Wood: decay, pests and protection. New York: Chapman \& Hall; 1993.

13. Siau JF. Flow in wood. Syracuse: Syracuse University Press; 1971.

14. Lepage EN. (Coord.). Manual de preservação de madeiras. São Paulo: IPT; 1986. 708 p. (Publicação IPT, 1637).

15. Latorraca JVF and Albuquerque CEC. Colagem varia de acordo com as propriedades da madeira. Revista da Madeira. 2005; 15(88):28-32.

16. ASSOCIAÇÃO BRASILEIRA DE NORMAS TÉCNICAS. NBR 7190: projeto de estruturas de madeira. Rio de Janeiro: ABNT; 1997.

17. Tappi Standard Methods. $T 264 \mathrm{~cm}-97$. Preparation of wood for chemical analysis. 1999.

18. Tappi Standard. T 211. Om-93. Ash in wood. 1985.

19. Tappi Standard. T 222. Om-98. Acid-insoluble lignin in wood and pulp. 1985.

20. Tappi Standard. T 250. Acid-soluble lignin in wood and pulp. 1985.

21. Tappi Standard. T 249. cm-85. Carbohydrate composition of extractivefree wood and wood pulp by gas-liquid chromatography. 1985.

22. Machado GO, Calil Jr C, Polito W and Pawlicka A. Preservante natural de madeira para uso na construção civil: óleo de Neem. Minerva. 2006; 3(1)1-8.

23. Kamke FA and Lee JN. Adhesive penetration in wood - a review. Wood and Fiber Science. 2007; 39(2):205-220.

24. Ferreira GW, Gonzaga JV, Foelkel CEB, Assis TF, Ratnieks E and Silva MCM. Qualidade da celulose kraft-antraquinona de Eucalyptus dunnii plantado em cinco espaçamentos em relação ao Eucalyptus grandis e Eucalyptus saligna. Ciência Florestal. 1997; 7(1):41-63.

25. Pinto EM. Determinação de um modelo para a taxa de carbonização transversal a grã para a madeira de E. citriodora e E. grandis. São Carlos: Universidade de São Paulo; 2005. [Tese de Doutorado].

26. Jankowsky IP and Galvão APM. Influência do teor de extrativos na umidade de equilíbrio da madeira. IPEF. 1979; 18:1-33.

27. Nearn WJ. Effect of water soluble extractives on the volumetric shrinkage and equilibrium moisture content of eleven tropical and domestic woods. Pennsylvania: Mont Alto; 1955.

28. Severo ETD, Calonego FW and Sansígolo CA. Composição química da madeira de Eucalyptus citriodora em função das direcções estruturais. Silva Lusitana. 2006; 14(1):113-126. 